\title{
A Role for Insulin-Like Growth Factor-I in the Regulation of Schwann Cell Survival
}

\author{
Daniel E. Syroid, ${ }^{1}$ Todd S. Zorick, ${ }^{1,3}$ Christophe Arbet-Engels, ${ }^{2}$ Trevor J. Kilpatrick, ${ }^{1}$ Walter Eckhart, ${ }^{2}$ and \\ Greg Lemke ${ }^{1}$ \\ ${ }^{1}$ Molecular Neurobiology Laboratory and ${ }^{2}$ Molecular Biology and Virology Laboratory, The Salk Institute for Biological \\ Studies, La Jolla, California 92037, and '3Department of Neurosciences, University of California San Diego, \\ La Jolla, California 92093
}

During postnatal development in the peripheral nerve, differentiating Schwann cells are susceptible to apoptotic death. Schwann cell apoptosis is regulated by axons and serves as one mechanism through which axon and Schwann cell numbers are correctly matched. This regulation is mediated in part by the provision of limiting axon-derived trophic molecules, although neuregulin-1 (NRG-1) is the only trophic factor shown to date to support Schwann cell survival. In this report, we identify insulin-like growth factor-I (IGF-I) as an additional trophin that can promote Schwann cell survival in vitro. We find that IGF-I, like NRG-1, can prevent the apoptotic death of postnatal rat Schwann cells cultured under conditions of serum withdrawal. Moreover, we show that differentiating Schwann cells in the rat sciatic nerve express both the IGF-I receptor (IGF-I R) and IGF-I throughout postnatal development. These results indicate that IGF-I is likely to control Schwann cell viability in the developing peripheral nerve and, together with other findings, raise the interesting possibility that such survival regulation may switch during postnatal development from an axon-dependent mechanism to an autocrine and/or paracrine one.

Key words: peripheral nervous system; glia; Schwann cell; myelination; apoptosis; insulin-like growth factor-I
Programmed death is a cell fate adopted by multicellular organisms to control cell number in development, homeostasis, and defense. Such physiological cell death, which most often proceeds through a series of well-defined alterations in cellular morphology termed apoptosis, is genetically programmed and results in cell suicide. Importantly, apoptosis must be tightly regulated such that only certain cells are specified to die, and it is now clear that both cell-extrinsic and cell-intrinsic signals can render cells susceptible to apoptosis (Steller, 1995; Fraser et al., 1996; White, 1996). During development, programmed cell death is often controlled by the positive selection of cells via specific ligand-receptor tyrosine kinase interactions.

Approximately $50 \%$ of immature postmitotic neurons normally undergo apoptotic death. In this instance, extrinsic signals delimit neuronal number and establish appropriate innervation patterns through competition for limiting target-derived trophins (Barde, 1989; Oppenheim, 1991). Death occurs when neurons fail to secure access to these trophins and consequently are unable to

Received Oct. 23, 1998; revised Dec. 22, 1998; accepted Dec. 28, 1998.

This work was supported by postdoctoral fellowships from the National Multiple Sclerosis Society to D.E.S. and from the Howard Hughes Medical Institute and the Bushell Fellowship of the Royal Australasian College of Physicians to T.J.K., by predoctoral fellowships from the Department of Defense and the National Institutes of Health to T.S.Z., and by grants from the National Institutes of Health to W.E. and G.L. We thank Danny Ortuño, Patrick Burrola, and Darcie Baynes for excellent technical assistance, Stefano Bertuzzi for help with RNase protection assays, Dan Peterson of the Gage laboratory for use of their confocal microscope, Jill Meisenhelder for peptide synthesis, and Bob Hyman for kindly providing anti-Thy-1 antibodies.

Correspondence should be addressed to Dr. Greg Lemke, Molecular Neurobiology Laboratory, The Salk Institute for Biological Studies, 10010 North Torrey Pines Road, La Jolla, CA 92037.

Dr. Kilpatrick's present address: Neuroimmunology Laboratory, Walter and Eliza Hall Institute of Medical Research, Royal Parade, Parkville 3052, Melbourne, Australia.

Copyright (ㄷ) 1999 Society for Neuroscience $\quad 0270-6474 / 99 / 192059-10 \$ 05.00 / 0$ suppress a constitutive cell death program (Raff, 1992; Raff et al., 1993). Apoptosis also occurs in differentiating oligodendrocytes and Schwann cells, the myelinating glial cells of the CNS and peripheral nervous system, respectively. Approximately $50 \%$ of newly generated oligodendrocytes die during development of the rodent optic nerve (Raff et al., 1993; Barres and Raff, 1994), and differentiating Schwann cells undergo apoptotic death during both embryonic (Ciutat et al., 1996) and early postnatal (Grinspan et al., 1996; Syroid et al., 1996; Nakao et al., 1997) development. Cell death in these glial lineages is thought to be in part regulated by the limited availability of axon-derived trophic factors and represents one mechanism whereby the appropriate stoichiometry between glia and the axons they myelinate is achieved (Raff et al., 1993; Barres and Raff, 1994; Zorick and Lemke, 1996).

Understanding the regulation of Schwann cell apoptosis requires an identification of the trophins that control Schwann cell viability. Apoptosis in Schwann cell precursors in vitro (Dong et al., 1995) and in postnatal Schwann cells in vivo (Grinspan et al., 1996; Trachtenberg and Thompson, 1996; Kopp et al., 1997) and in vitro (Syroid et al., 1996) can be prevented by neuregulin-1 (NRG-1), which is normally supplied by axons (Carraway and Burden, 1995; Lemke, 1996). Another set of factors that may mediate Schwann cell survival is the insulin-like growth factors (IGFs)-I and -II. As autocrine and/or paracrine factors, the IGFs are thought to play an important role in the development and regeneration of the nervous system (Hansson, 1993; Ishii et al., 1993; Lewis et al., 1993a; de Pablo and de la Rosa, 1995). IGF-I, for example, regulates oligodendrocyte development and myelination in vitro and in vivo (McMorris et al., 1986, 1993; McMorris and Dubois-Dalcq, 1988; Saneto et al., 1988; Mozell and McMorris, 1991; Barres and Raff, 1994; Yao et al., 1995). Reduced 
oligodendrocyte numbers and a severe myelination defect have been observed in IGF-I and IGF-I receptor (IGF-I R) mutant mice (Liu et al., 1993; Beck et al., 1995), and a corresponding enhancement of myelin content has been noted in transgenic mice that overexpress IGF-I (Carson et al., 1993; Ye et al., 1995). For the Schwann cell lineage, both IGF-I and IGF-II can potentiate the survival of cultured Schwann cell precursors (Gavrilovic et al., 1995) and can act as mitogens and differentiation factors for postnatal Schwann cells in vitro (Schumacher et al., 1993; Stewart et al., 1996). In this report, we provide evidence that IGF-I acts as an autocrine and/or paracrine survival factor for postnatal Schwann cells.

\section{MATERIALS AND METHODS}

Cell culture. Schwann cells were prepared from postnatal day 3 (P3) rat sciatic nerve and purified to $>99.5 \%$ homogeneity essentially as described previously (Brockes et al., 1979). Cells were routinely maintained by plating on poly-L-lysine ( $100 \mu \mathrm{g} / \mathrm{ml}$; Sigma, St. Louis, MO)-coated 10 $\mathrm{cm}$ tissue culture Petri dishes (Falcon) in DMEM (Life Technologies, Gaithersburg, MD) containing fetal calf serum (FCS; 10\%; HyClone, Logan, UT), forskolin (Fsk; $2 \mu \mathrm{M}$; Calbiochem, La Jolla, CA), and recombinant NRG-1 $\beta$ [NRG- $\beta$; amino acids 177-228 encompassing the $\beta$-type epidermal growth factor-like domain (Lemke, 1996)] (10 ng/ml). These represent the preassay conditions for all experiments. Schwann cells grown on eight-well chamber slides (Lab-Tek) were plated on poly-L-lysine $(100 \mu \mathrm{g} / \mathrm{ml})$ and laminin $(10 \mu \mathrm{g} / \mathrm{ml}$; Life Technologies). Schwann cell survival assays were performed as described previously (Syroid et al., 1996).

Growth factors. Human IGF-I and IGF-II were from Boehringer Mannheim (Indianapolis, IN). Human recombinant NRG- $\beta$ was kindly provided by Dr. Duanzhi Wen (Amgen, Thousand Oaks, CA). Bovine serum albumin (BSA; Sigma; 0.1\% final) was added to all growth factors as a carrier protein.

Generation of IGF-I receptor antibody. New Zealand White rabbits were immunized with a peptide corresponding to the C-terminal 14 amino acids (KNERALPLPQSSTC) of the $\beta$-subunit of the IGF-I R cross-linked to keyhole limpet hemocyanin with glutaraldehyde. IGF-I R antibody was affinity-purified using an affinity column containing the peptide covalently coupled to cyanogen bromide-activated sepharose beads (Pharmacia, Piscataway, NJ) and then was eluted using $0.1 \mathrm{M}$ glycine, $\mathrm{pH} 2.5$, and $0.1 \mathrm{M}$ ethanolamine, $\mathrm{pH} 11.5$. The two fractions were pooled and dialyzed against PBS buffer (137 mM NaCl, $2.7 \mathrm{~mm} \mathrm{KCl}, 4.3$ $\mathrm{mm} \mathrm{Na} \mathrm{HPO}_{4} \cdot 7 \mathrm{H}_{2} \mathrm{O}$, and $1.4 \mathrm{~mm} \mathrm{KH}_{2} \mathrm{PO}_{4}, \mathrm{pH}$ 7.3). The IGF-I R antibody was then partially concentrated by centrifugation through a Centriprep 10,000 filter (Amicon, Beverly, MA).

The specificity of the IGF-I R antibody was examined by immunoprecipitation of the IGF-I R from lysates of $\left[{ }^{35}\right.$ S $]$ methionine-labeled 293 and NIH3T3 cells. A $97 \mathrm{kDa}$ protein corresponding to the IGF-I R $\beta$-subunit was selectively immunoprecipitated by the IGF-I R antibody and not by the preimmune serum. Preincubation of the IGF-I R antibody with an excess of the IGF-I R peptide inhibited immunoprecipitation of the 97 $\mathrm{kDa}$ protein. Similarly, the mouse monoclonal antibody directed against the $\alpha$-subunit of the IGF-I R ( $\alpha$ IR3; Oncogene Research Products) coimmunoprecipitated the $97 \mathrm{kDa}$ IGF-I R $\beta$-subunit. This protein comigrated with the protein immunoprecipitated with the IGF-I R antibody, and both antibodies yielded similar amounts of immunoprecipitated IGF-I R $\beta$-subunit. Western blot analyses confirmed that the 97 $\mathrm{kDa}$ immunoprecipitated protein corresponded to the $\beta$-subunit of the IGF-I R. Furthermore, transfection of NIH3T3 cells with the human IGF-I R cDNA resulted in a dramatic increase in the detection of the 97 $\mathrm{kDa}$ IGF-I R protein. Increased tyrosine phosphorylation of the IGF-I R $\beta$-subunit was also observed in an anti-phosphotyrosine Western blot after stimulation of cells with IGF-I. Cross-reactivity of the IGF-I R antibody with the insulin receptor was examined using immunoprecipitation and Western blot analyses of cells isolated from IGF-I R - /- mice (Liu et al., 1993). Detection by the Enhanced Chemiluminescence kit (Amersham, Arlington Heights, IL) did not reveal a $97 \mathrm{kDa}$ protein even after prolonged exposures. Data supporting the integrity of the IGF-I R antibody are not shown here (Arbet-Engels et al., 1999). For immunohistochemical analyses, preincubation of IGF-I R antibody with IGF-I R peptide specifically precluded IGF-I R immunoreactivity on P8 rat sciatic nerve sections in a dose-dependent manner (data not shown).
Antibodies. Mouse monoclonal anti-neurofilament (NF) antibody (Sigma) was used at 1:100 dilution. Mouse monoclonal anti-protein zero $\left(\mathrm{P}_{0}\right)$ antibody was kindly provided by Dr. J. J. Archelos (Bayerische JuliusMaximilians-Universität, Würzburg, Germany) and used at 1:2000 dilution. Rabbit antiserum to IGF-I (UB2-495) was kindly provided by the National Institute of Diabetes and Digestive and Kidney Diseases (NIDDK), National Hormone and Pituitary Program, by Drs. Louis E. Underwood and Judson J. Van Wyk (University of North Carolina, Chapel Hill, NC) and used at 1:20 dilution. Affinity-purified rabbit polyclonal anti-IGF-I R antibody was used undiluted.

MTT survival assay. MTT [3-(4,5-dimethylthiazol-2-yl)-2,5-diphenyltetrazolium bromide; Sigma] was added to cells at a concentration of 0.5 $\mathrm{mg} / \mathrm{ml}$, and the cells were then further incubated at $37^{\circ} \mathrm{C}$ for $1 \mathrm{hr}$. The number of cells in the bottom of each well exhibiting a positive blue granular reaction product was assessed using bright-field microscopy.

$\left[{ }^{3} H\right]$ Thymidine incorporation assay. Schwann cells were dissociated by trypsinization, washed once in DMEM containing $10 \%$ FCS to inactivate the trypsin, and then washed an additional five times in cold serum-deficient DMEM to remove serum. Cells were plated onto eightwell chamber slides $(10,000$ cells/well) in either DMEM containing $10 \%$ FCS, Fsk $(2 \mu \mathrm{m})$, and NRG- $\beta(50 \mathrm{ng} / \mathrm{ml})$ or IGF-I $(50 \mathrm{ng} / \mathrm{ml})$, DMEM containing IGF-I only $(50 \mathrm{ng} / \mathrm{ml})$, or DMEM containing BSA only. Each culture condition was performed in duplicate. $\left[{ }^{3} \mathrm{H}\right]$ Thymidine (Amersham) was then added to all wells at a concentration of $0.03 \mu \mathrm{Ci} / \mathrm{ml}$, and after a further $24 \mathrm{hr}$ the cells were fixed for $20 \mathrm{~min}$ at room temperature in $4 \%$ paraformaldehyde/PBS buffer. Processing of slides and assessment of $\left[{ }^{3} \mathrm{H}\right]$ thymidine incorporation in two independent experiments were as described previously (Syroid et al., 1996). Cells that had four or more silver grains over their nuclei were considered to be $\left[{ }^{3} \mathrm{H}\right]$ thymidine-positive.

Ribonuclease protection analysis. Total cellular RNA from cultured Schwann cells and Sprague Dawley rat sciatic nerves was prepared and analyzed by ribonuclease protection assay as described previously (Chomczynski and Sacchi, 1987; Krieg and Melton, 1987). Antisense RNA probes were synthesized using the Maxiscript in vitro transcription kit (Ambion) from templates containing the following inserts: a 690 base pair Sau3A-NlaIV fragment containing rat IGF-I genomic sequences encompassing exons 1, 3, and 4 (Adamo et al., 1991); a 265 base pair $E c o$ RI- $R s a$ I rat IGF-I R cDNA fragment encompassing $5^{\prime}$-untranslated sequences, the coding region for the signal peptide, and the first 53 amino acids of the $\alpha$-subunit (Werner et al., 1989) (both templates kindly provided by Dr. Derek LeRoith, Diabetes Branch, NIDDK, National Institutes of Health, Bethesda, MD); and a 150 base pair mouse cyclophilin cDNA fragment encompassing 3'-untranslated sequences [nucleotides 586-736 (Hasel and Sutcliffe, 1990)]. This cyclophilin RNA probe gives rise to multiple protected RNA fragments (150 base pairs and lower molecular weight species) when hybridized with the rat RNA used in this study because of several nucleotide mismatches with the corresponding rat cyclophilin cDNA sequence (Danielson et al., 1988). Cyclophilin RNA probes of low specific activity were generated by including $0.05 \mathrm{~mm}$ UTP in transcription reactions and using only onefifth $(10 \mu \mathrm{Ci})$ of the usual amount of $\left[\alpha^{-32} \mathrm{P}\right] \mathrm{UTP}$ (Amersham). RNA $(1-18 \mu \mathrm{g})$ or tRNA $(10 \mu \mathrm{g})$ was cohybridized with $80,000 \mathrm{cpm}$ of either IGF-I or IGF-I R RNA probe and 30,000 cpm of cyclophilin RNA probe, as indicated. The relative quantity and integrity of RNA used in each experiment were confirmed on agarose gels (data not shown). Protected probe/RNA hybrids were resolved on $6 \%$ polyacrylamide and $8 \mathrm{M}$ urea denaturing gels.

Sciatic nerve transection. Adult and P1 Sprague Dawley rats were gas anesthetized using isoflurane, and unilateral sciatic nerve transections were performed just proximal to the sciatic notch as described previously (Zorick et al., 1996). Nerve sections (3-5 mm) were excised to prevent axon regrowth within the time frame of the experiment. Animals were killed either $24 \mathrm{hr}$ or $7 \mathrm{~d}$ after transection, at which time both the unlesioned contralateral sciatic nerve and the entire length of the distal stump of the transected nerve were isolated and processed for RNA preparation. Distal stumps of transected nerves were closely examined before isolation to ensure that regeneration was completely precluded.

Immunohistochemical staining. Immunohistochemical staining of rat sciatic nerve sections was performed as described previously (Zorick et al., 1996). For fluorescence microscopy, immunolabeled sections were incubated for $1 \mathrm{hr}$ at $25^{\circ} \mathrm{C}$ with anti-rabbit/FITC and/or anti-mouse/ Texas Red secondary antibodies (1:100; Jackson ImmunoResearch, West Grove, PA). Frozen cross sections of rat sciatic nerves were prepared as described previously (Syroid et al., 1996; Zorick et al., 1996). 


\section{RESULTS}

\section{IGF-I inhibits Schwann cell death in vitro}

We have shown previously that Schwann cells isolated from P3 rat sciatic nerve undergo apoptosis in vitro after serum withdrawal and that $\beta$-isoforms of NRG-1 (NRG- $\beta$ ) can prevent this apoptotic death (Syroid et al., 1996). To assess further the survival requirements of postnatal Schwann cells, we examined whether IGF-I or IGF-II can promote Schwann cell viability in vitro under serum-free conditions using an MTT incorporation assay. MTT is a chromogenic reagent that is converted to a granular blue product when metabolized by active mitochondria. As shown in Figure $1 A$, only $15-20 \%$ of cells remain viable $3 \mathrm{~d}$ after serum withdrawal when plated in DMEM in the absence of exogenous trophic factors (e.g., in BSA alone). However IGF-I (50 ng/ml), like NRG- $\beta$, can effectively maintain Schwann cell number at $\sim 80 \%$ of the initial plating number. In contrast, IGF-II at the same concentration only partially inhibits Schwann cell death, a result that may reflect the reduced affinity of IGF-II for the IGF-I $\mathrm{R}$ (Jones and Clemmons, 1995). The ability of IGF-I to prevent Schwann cell death was dose-dependent, exhibiting a dose response similar to that of NRG- $\beta$ (Fig. $1 B$ ). Schwann cells cultured in serum-deficient DMEM containing IGF-I converted MTT into high levels of the chromogenic blue reaction product (Fig. 1C), an activity that was also dose-dependent (data not shown). These observations are indicative of strong metabolic activity in these cells, which were elongated and bipolar in morphology and displayed extended processes, features characteristic of healthy cultured Schwann cells. The few weakly MTT-positive Schwann cells observed in serum-deficient DMEM containing only BSA were rounded and lacked processes (Fig. 1C, arrows). Both these cells and MTT-negative cells exhibited extensive nuclear fragmentation and chromatin condensation (Syroid et al., 1996), which are characteristic features of apoptotic cells (compare also with Fig. $2 C, D$ ). Viable cells cultured in DMEM containing only IGF-II gave rise to a less intense MTT reaction product than did those cultured in IGF-I (data not shown), results that are in keeping with the more modest ability of IGF-II to promote Schwann cell survival (Fig. 1A).

\section{IGF-I is a survival factor for postnatal Schwann cells}

To address the possibility that IGF-I-mediated maintenance of Schwann cell number under serum-free conditions (Fig. 1A) might be caused by the induced proliferation of a subset of cells refractory to cell death, we performed $\left[{ }^{3} \mathrm{H}\right]$ thymidine incorporation assays. As shown for a positive control, the majority of cells cultured under proliferative conditions in the combined presence of Fsk and NRG- $\beta$ incorporated $\left[{ }^{3} \mathrm{H}\right]$ thymidine (Fig. $2 A ; 86 \%$ of nuclei labeled; 1566 nuclei counted) (Syroid et al., 1996). Similarly and as reported previously (Schumacher et al., 1993; Stewart et al., 1996), IGF-I is also mitogenic for Schwann cells when combined with Fsk (Fig. 2B; $87 \%$ of nuclei labeled; 1811 nuclei counted). However, cells subjected to serum withdrawal were not labeled when cultured in DMEM containing IGF-I alone (Fig. $2 C ; 0.01 \%$ of nuclei labeled; 1721 nuclei counted), indicating that IGF-I is not mitogenic for Schwann cells under these conditions. As expected, cells grown in DMEM containing only BSA (most of which were dead or dying) also failed to incorporate $\left[{ }^{3} \mathrm{H}\right]$ thymidine (Fig. 2D; $0.002 \%$ of nuclei labeled; 1614 nuclei counted). These results demonstrate that IGF-I can function as a survival factor for cultured postnatal Schwann cells.

\section{Schwann cells express the IGF-I receptor in vitro}

The IGF-I $\mathrm{R}$ is a receptor tyrosine kinase composed of two ligand-binding extracellular $\alpha$-subunits associated with two transmembrane kinase domain-containing $\beta$-subunits that transduces both IGF-I and IGF-II signals (Jones and Clemmons, 1995; LeRoith et al., 1995). It has been demonstrated previously that proliferating Schwann cells express the IGF-I R in vitro (Schumacher et al., 1993; Stewart et al., 1996). To examine whether Schwann cells cultured under apoptotic, serum-free conditions (those used for the assays of Fig. 1) also express the IGF-I R, a ribonuclease protection analysis was performed using total RNA derived from rat Schwann cells at 4 and $24 \mathrm{hr}$ after plating in unsupplemented DMEM and from Schwann cells maintained for $48 \mathrm{hr}$ in DMEM containing serum and stimulated with $20 \mu \mathrm{M}$ Fsk, conditions that lead to the induction of myelin-specific genes and thus represent an in vitro paradigm for differentiating Schwann cells (Lemke and Chao, 1988). As shown in Figure 3A, the IGF-I R RNA probe was specifically protected under all conditions and gave rise to the expected 265 base pair-protected fragment (Werner et al., 1989). These results demonstrate that the IGF-I R proreceptor mRNA is expressed both in Fsk-stimulated Schwann cells and in Schwann cells cultured in the absence of serum.

\section{Schwann cells are induced to express IGF-I in vitro when switched to unsupplemented medium}

Because Schwann cells require the exogenous provision of IGF-I to prevent their apoptotic death in vitro (Fig. $1 A$ ), we reasoned that cells cultured under apoptotic, serum-free conditions do not express IGF-I. To examine this possibility directly, a ribonuclease protection assay was performed using total RNA isolated from both Fsk-stimulated Schwann cells and Schwann cells subjected to serum withdrawal, as described above. As shown in Figure $3 B$, IGF-I mRNA was not detected in Fsk-stimulated Schwann cells even after extended autoradiographic exposure. As expected, IGF-I expression was also absent in preassay Schwann cellsSchwann cells cultured in DMEM containing serum and $2 \mu \mathrm{M}$ Fsk (data not shown). Interestingly, a very low level of IGF-I mRNA was detected after Schwann cells were cultured for $4 \mathrm{hr}$ in unsupplemented DMEM, and this expression was upregulated after $24 \mathrm{hr}$ (Fig. $3 B$ ), a time at which $\sim 50 \%$ of cells are already dead (Fig. 1A) (Syroid et al., 1996). The multiple protected IGF-I RNA probe fragments evident in Figure $3 B$ derive from a heterogeneous population of IGF-I transcripts resulting from multiple major transcription initiation sites within exon 1 of the IGF-I gene and correspond to the previously reported protected fragments of 573, 530, and 428 base pairs. [Additional lower molecular weight protected fragments were also detected and probably reflect additional downstream transcription initiation sites (data not shown) (Adamo et al., 1991).] Because the majority of Schwann cells become committed to a pathway of apoptotic death at 2-4 hr after serum withdrawal (Syroid et al., 1996), an IGF-I-mediated autocrine mechanism in early IGF-I-producing cells may account for the $15-20 \%$ of cells that survive prolonged serum-deficient culture (Fig. 1A). These surviving cells are unlikely to represent a distinct Schwann cell population present in the nerve at the time of dissociation, because much previous work (e.g., Lemke and Chao, 1988) has suggested that essentially all neonatal Schwann cells, independent of their differentiation state at the time of dissociation, are phenotypically plastic and revert to a common embryonic phenotype after being placed in DMEM supplemented with serum alone. 


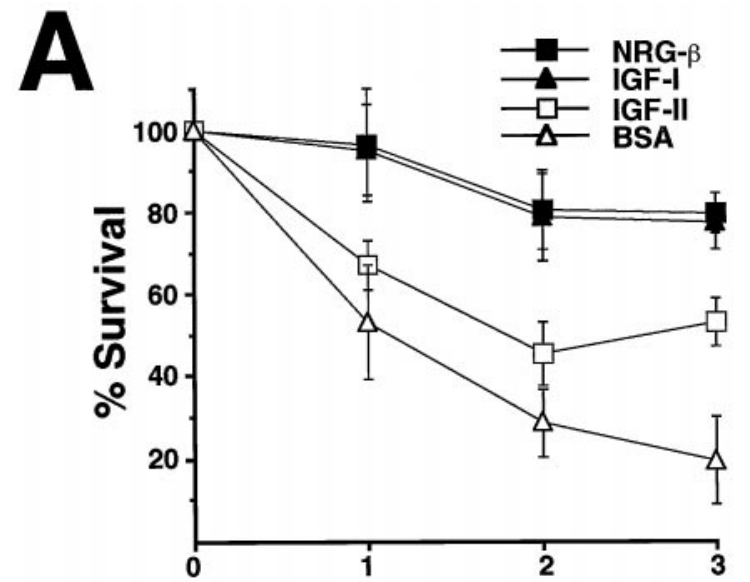

Days Post Serum Withdrawal
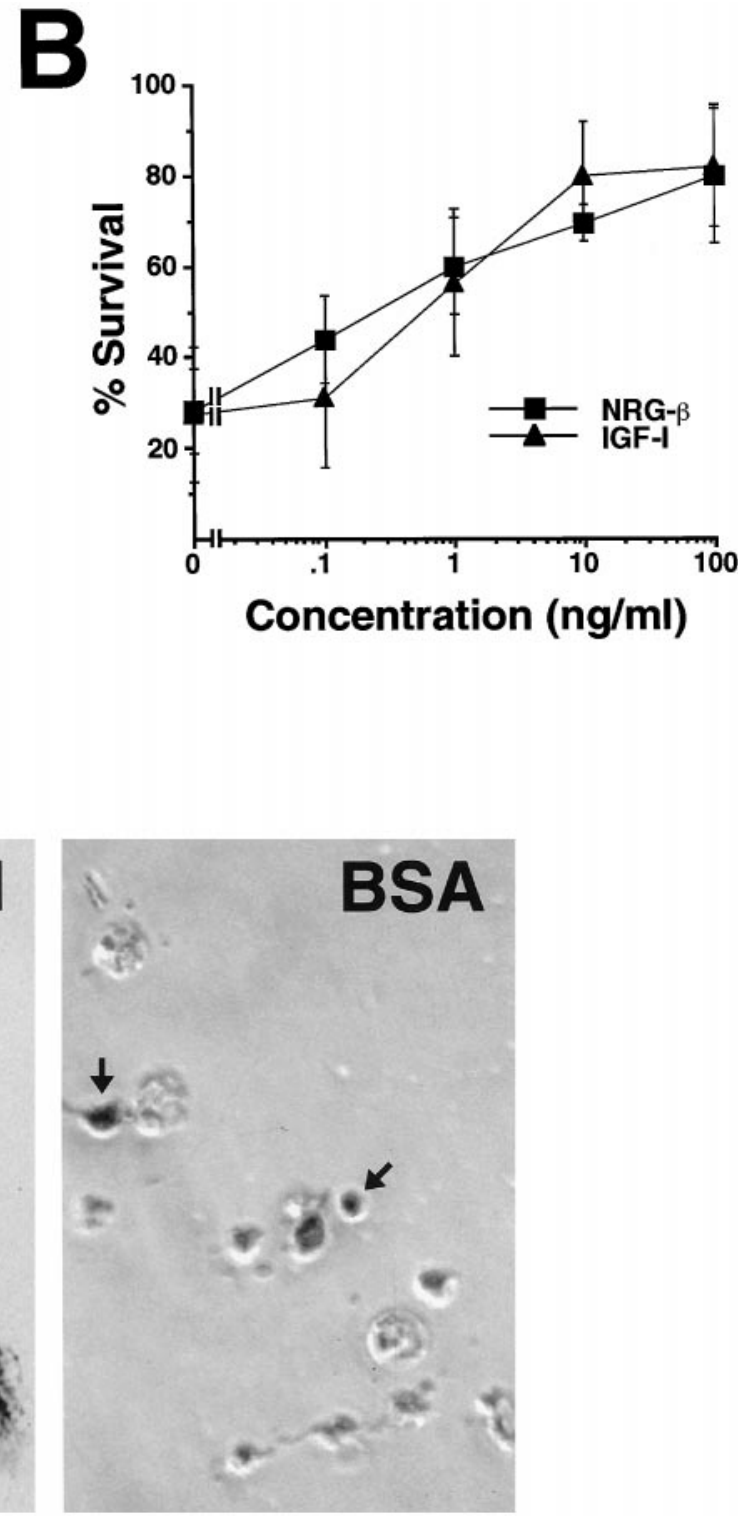

Figure 1. IGF-I promotes the survival of postnatal Schwann cells in vitro. Schwann cells were washed five times in serum-deficient DMEM to remove serum and then plated on multiple microwell plates in DMEM either in the presence of the factor indicated or with $B S A$. Viable cells were identified and counted using an MTT incorporation assay at daily intervals over a $3 \mathrm{~d}$ period. $A, I G F-I$, like $N R G-\beta$, can promote Schwann cell survival, whereas $B S A$ cannot. $I G F-I I$ can only partially inhibit Schwann cell death. B, Dose-response curves for $I G F-I-$ and $N R G$ - $\beta$-mediated Schwann cell survival 3 d after serum withdrawal demonstrate that these factors exhibit comparable survival activities. $C$, MTT assay for Schwann cell viability 24 hr after serum withdrawal shows the cellular morphology and the strong MTT positivity of Schwann cells cultured in DMEM in the presence of $I G F-I$, as analyzed by phase contrast microscopy. Arrows denote the few remaining viable, weakly MTT-positive Schwann cells in the BSA-negative control. Factor concentration was $50 \mathrm{ng} / \mathrm{ml}$ unless otherwise indicated. Error bars represent the SD from the mean in survival activity derived from at least three separate experiments. Scale bar, $5 \mu \mathrm{m}$.

\section{Schwann cells express the IGF-I receptor in the developing sciatic nerve}

To assess the in vivo relevance of our in vitro results, the expression of both the IGF-I R and IGF-I was examined in rat sciatic nerves during the first 2 postnatal weeks, the time at which Schwann cells are maximally susceptible to apoptotic death (Grinspan et al., 1996; Syroid et al., 1996; Nakao et al., 1997). Sciatic nerves were isolated at various postnatal days, and either total RNA was prepared and used for ribonuclease protection analyses to examine mRNA expression or nerves were processed for sectioning and subjected to immunohistochemical analyses to examine protein expression.
As shown in Figure $4 A$, ribonuclease protection detected the IGF-I R proreceptor transcript as early as the day of birth (P0), and mRNA expression was maintained thereafter, into the mature nerve. Because Schwann cells make up the vast majority of mRNA-containing cells in the peripheral nerve, it is likely that they are responsible for the observed IGF-I R mRNA expression. To examine directly which cells express the IGF-I R, immunohistochemical analyses were performed on P10 sciatic nerve cross sections using a polyclonal antibody to the IGF-I R (Arbet-Engels et al., 1999). This antibody was generated using a synthetic peptide comprising the C-terminal 14 amino acids of the $\beta$-subunit of the IGF-I R (see Materials and Methods) and was 

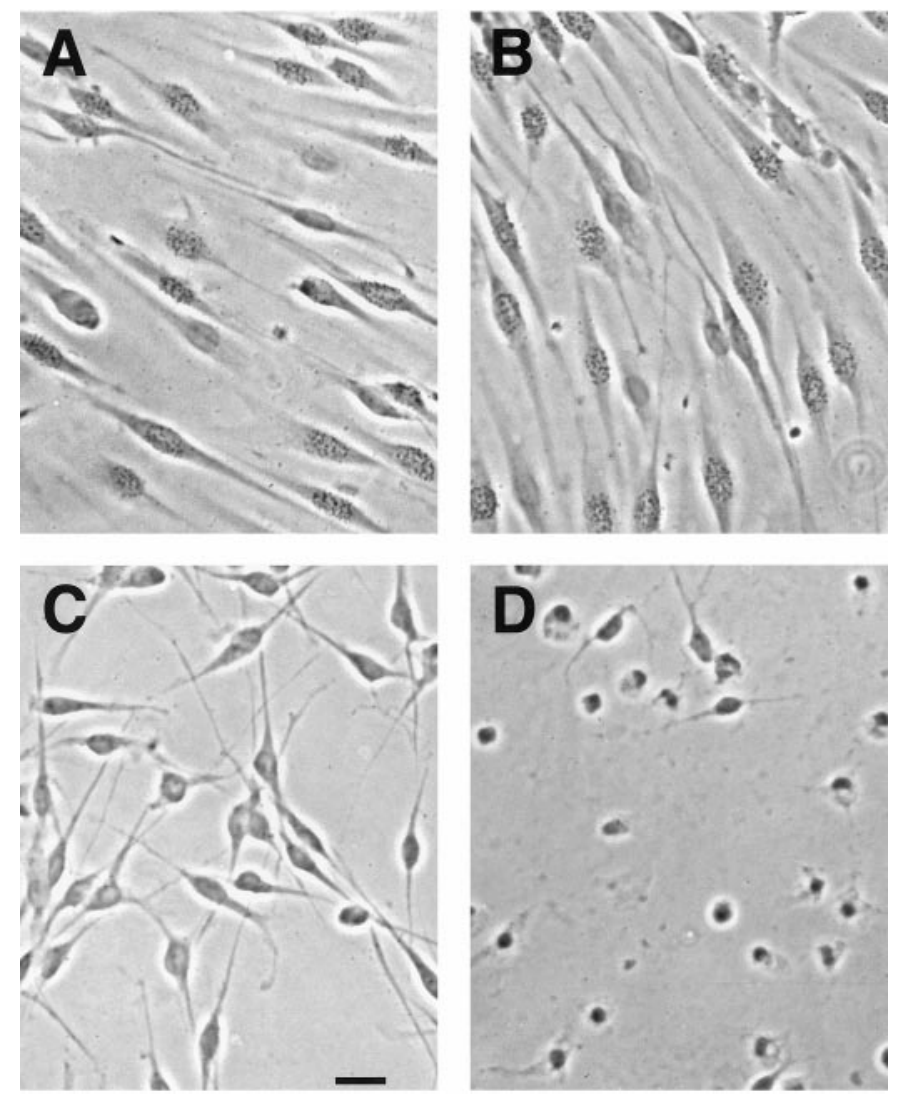

Figure 2. IGF-I is a Schwann cell survival factor in vitro. Schwann cells were subjected to serum withdrawal and then cultured for $24 \mathrm{hr}$ on eight-well chamber slides in DMEM containing either $10 \%$ FCS, NRG- $\beta$ $(50 \mathrm{ng} / \mathrm{ml})$, and Fsk $(2 \mu \mathrm{M})(A) ; 10 \% \mathrm{FCS}$, IGF-I $(50 \mathrm{ng} / \mathrm{ml})$, and Fsk $(2$ $\mu \mathrm{M})(B) ; \mathrm{IGF}-\mathrm{I}(50 \mathrm{ng} / \mathrm{ml})(C)$; or BSA $(D) .\left[{ }^{3} \mathrm{H}\right]$ Thymidine $(0.03$ $\mu \mathrm{Ci} / \mathrm{ml})$ was then added, and the cells were further incubated for $24 \mathrm{hr}$, after which the cells were fixed and $\left[{ }^{3} \mathrm{H}\right]$ thymidine incorporation was assessed by phase contrast microscopy. Schwann cells cultured in the presence of IGF-I under conditions of serum withdrawal $(C)$ do not incorporate $\left[{ }^{3} \mathrm{H}\right]$ thymidine, indicating that IGF-I is mediating survival activity. Scale bar, $5 \mu \mathrm{m}$.

chosen for our study because it generates much less background than do commercially available antibodies against the IGF-I R $\alpha$-subunit (data not shown). As shown in Figure $5 A$, Schwann cells of P10 sciatic nerve exhibit strong IGF-I R immunoreactivity. IGF-I R expression was detected from the day of birth onward (data not shown), results that are in agreement with the IGF-I R transcript expression profile (Fig. 4A). As reported previously (Caroni and Grandes, 1990; Lewis et al., 1993b; Reinhardt et al., 1993), we find that axons also display low IGF-I R immunoreactivity (Fig. 5A).

\section{Schwann cells express IGF-I in the developing sciatic nerve}

To determine whether IGF-I is expressed in the rat sciatic nerve during postnatal development, a ribonuclease protection analysis was performed using total RNA derived from sciatic nerves isolated at various stages of postnatal development. As shown in Figure $4 B$, multiple IGF-I transcripts were detected at the day of birth, and mRNA expression was maintained thereafter, both throughout postnatal development and within the adult nerve. To examine whether Schwann cells account for this expression, double-labeling immunohistochemical analyses were performed on cross sections of $\mathrm{P} 10$ rat sciatic nerve using a polyclonal antiserum to IGF-I, an antiserum that has been used previously to examine IGF-I protein expression in vivo in rat sciatic nerve (Cheng et al., 1996), and using antibodies to axon-specific NF and peripheral myelin $\mathrm{P}_{0}$. As shown in Figure $5 B$, IGF-I immunoreactivity strongly localizes to the cytoplasm of Schwann cells. Consistent with the IGF-I mRNA profile (Fig. 4B), Schwann cell expression of IGF-I is maintained throughout postnatal development and in the mature nerve (data not shown). Although IGF-I appears to be excluded from the myelin sheath (marked by $\mathrm{P}_{0}$ ), a very low level of IGF-I immunoreactivity also localizes to axons [Fig. 5B, bottom (IGF-I alone)]. These results, taken together, demonstrate that Schwann cells are the major source of IGF-I in the postnatal rat sciatic nerve and are in agreement with previous work implicating axons as an additional source of IGF-I in developing and mature peripheral nerves (D. E. Syroid and G. Lemke, unpublished observations) (Hansson et al., 1987; Garcia-Segura et al., 1991; Lievre et al., 1991).

\section{Developing Schwann cells maintain expression of the IGF-I receptor and IGF-I after loss of axonal contact}

There is considerable evidence implicating IGF-I as an important trophic molecule in the regeneration of the nervous system (Hansson, 1993; Ishii et al., 1993; Lewis et al., 1993a; de Pablo and de la Rosa, 1995), and consistent with this view, several studies report the induction of IGF-I in both injured and regenerating peripheral nerves. For example, increased IGF-I immunoreactivity has been noted in both Schwann cells and axons proximal to the site of lesion in adult sciatic nerve and, to a lessor degree, in Schwann cells of the distal nerve stump undergoing Wallerian degeneration (Hansson et al., 1986, 1987, 1988; Hansson, 1993). Upregulation of IGF-I and IGF-I R mRNA has also been reported in both proximal and distal nerve stumps after mature sciatic nerve transection (Glazner et al., 1994; Pu et al., 1995; Cheng et al., 1996). Interestingly, mature Schwann cells remain viable, at least over several weeks, after loss of axonal contact in the adult nerve (D. E. Syroid, T. J. Kilpatrick, and G. Lemke, unpublished observations) (Weinberg and Spencer, 1978; Grinspan et al., 1996), whereas developing Schwann cells in the neonatal nerve undergo apoptosis within $24 \mathrm{hr}$ of transection (Grinspan et al., 1996; Trachtenberg and Thompson, 1996; Kopp et al., 1997). Because IGF-I is a potent survival factor for postnatal Schwann cells and because Schwann cells synthesize IGF-I during postnatal development (this study), it is conceivable that the observed induction of Schwann cell death in neonatal nerves undergoing Wallerian degeneration may be caused by a corresponding impairment in IGF-I signaling. Expression of the IGF-I $\mathrm{R}$ and IGF-I was therefore examined in both neonatal (P1) and adult rat sciatic nerves during Wallerian degeneration. Unilateral sciatic nerve transections were performed, and both the distal stump of lesioned nerves and the intact contralateral nerves were isolated $24 \mathrm{hr}$ after transection; total RNA was prepared and used for ribonuclease protection analyses. As an additional control, IGF-I R and IGF-I expression was examined $7 \mathrm{~d}$ after transection in adult distal nerve stumps, a sufficient period in the mature nerve for axonal degeneration. As shown in Figure 6, $A$ and $B$, expression of the IGF-I R proreceptor transcript and the multiple IGF-I transcripts, respectively, in the distal stump of transected $\mathrm{P} 1$ nerves is maintained at approximately the same level relative to that in transected adult nerves, at both $24 \mathrm{hr}$ and $7 \mathrm{~d}$ after transection. Moreover, IGF-I $\mathrm{R}$ and IGF-I expression in transected nerves is no different relative to that in the corre- 


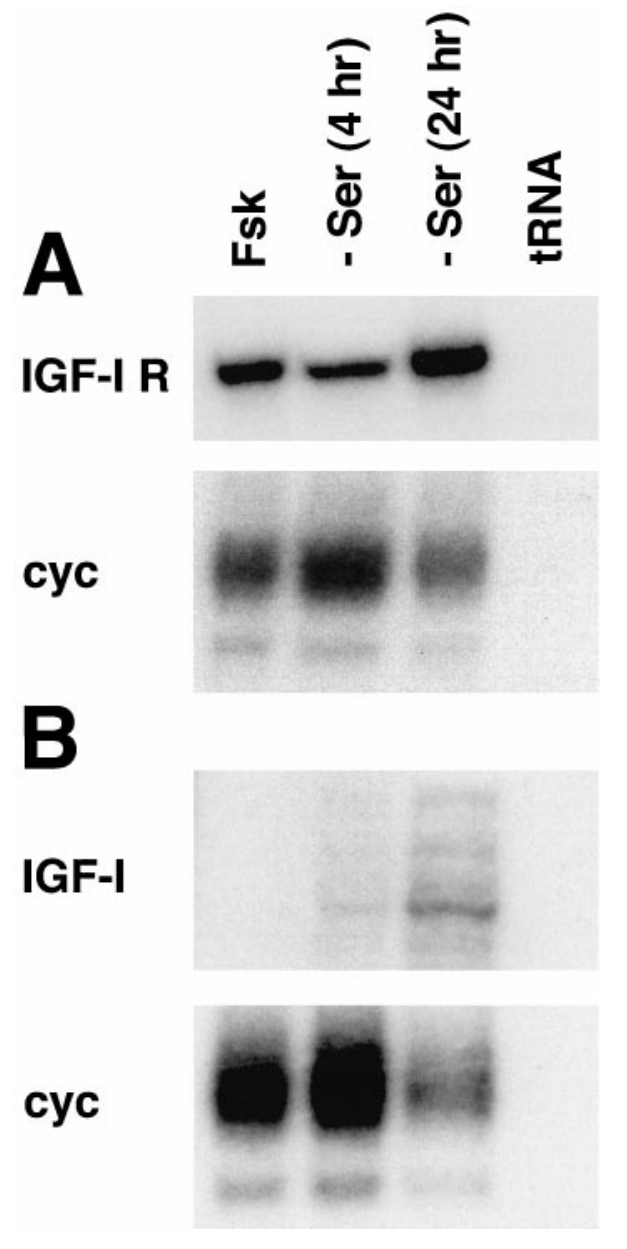

Figure 3. Schwann cells express both IGF-I $R$ and IGF-I mRNAs in vitro. Ribonuclease protection analyses were performed using total RNA (6 or $18 \mu \mathrm{g}$ per hybridization reaction with $I G F-I R$ or $I G F-I$ RNA probes, respectively) isolated from subconfluent Schwann cells cultured either in DMEM containing 10\% FCS and $20 \mu \mathrm{M}$ Fsk $(F s k)$ or in DMEM alone (-Ser) for 4 or $24 \mathrm{hr}$ or using $10 \mu \mathrm{g}$ of $t R N A$ as a negative control, as indicated. $A$, The $I G F-I R$ is expressed by Schwann cells grown in serumand $F s k$-supplemented DMEM and by cells cultured in DMEM alone. Autoradiographic exposure was $10 \mathrm{hr}$. $B, I G F-I$ is not expressed in Schwann cells grown in DMEM containing serum and forskolin; however a very low level of $I G F-I$ mRNA can be detected in Schwann cells cultured for $4 \mathrm{hr}$ in unsupplemented DMEM, and this expression is upregulated after $24 \mathrm{hr}$. Autoradiographic exposure was $63 \mathrm{hr}$. Bottom $(A, B)$, The relative cyclophilin RNA level ( cyc) from corresponding cohybridization reactions using a cyclophilin-loading control probe is shown. Autoradiographic exposure in these panels was $18 \mathrm{hr}(A)$ and $5 \mathrm{hr}(B)$.

sponding contralateral control nerves. Previous reports have suggested that these mRNAs are even upregulated in adult sciatic nerves undergoing Wallerian degeneration (Glazner et al., 1994; Pu et al., 1995; Cheng et al., 1996), although we have not observed this. In any event, our results indicate that developing Schwann cells in the neonatal sciatic nerve maintain expression of both IGF-I and the IGF-I R after loss of axonal contact and that the level of expression appears to be comparable with that of Schwann cells found in mature nerves undergoing Wallerian degeneration.

\section{DISCUSSION}

In this study, we demonstrate that IGF-I is a survival factor for postnatal rat Schwann cells in vitro and that IGF-I-mediated

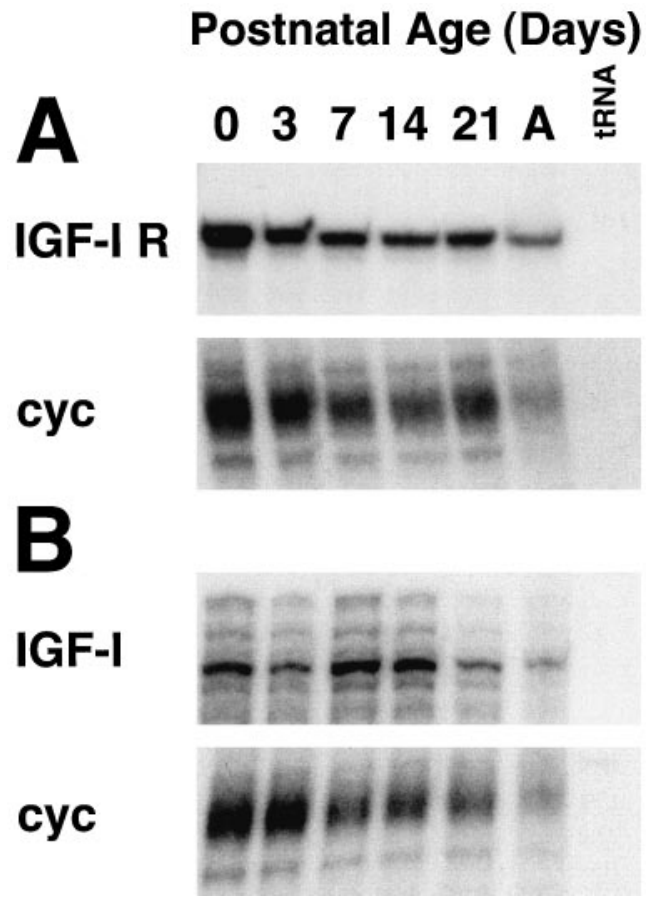

Figure 4. The IGF-I $R$ and IGF-I mRNAs are expressed in the sciatic nerve throughout postnatal development. Ribonuclease protection analyses were performed using total RNA ( $6 \mu \mathrm{g}$ per hybridization reaction) isolated from adult rat sciatic nerves $(A)$ and nerves at various stages of postnatal development or using $10 \mu \mathrm{g}$ of $t R N A$ as a negative control, as indicated. $A, B$, The $I G F-I R(A)$ and $I G F-I(B)$ are expressed throughout postnatal development and in the adult nerve. Autoradiographic exposure was $18 \mathrm{hr}(A)$ and $24 \mathrm{hr}(B)$. Bottom $(A, B)$, The relative cyclophilin RNA level $(c y c)$ from corresponding cohybridization reactions using a cyclophilin probe is shown. Autoradiographic exposure in these panels was 75 hr $(A)$ and $24 \mathrm{hr}(B)$.

survival activity is almost certainly transduced via the IGF-I R. We also demonstrate that differentiating Schwann cells in the rat sciatic nerve express both IGF-I and the IGF-I R throughout postnatal development and that IGF-I and IGF-I R expression by both developing and mature Schwann cells is maintained during Wallerian degeneration. These results implicate an IGF-I-mediated autocrine loop in Schwann cell survival regulation.

Schwann cell number is tightly controlled during early postnatal development, and this regulation is mediated by the action of multiple axon-associated signals that modulate both Schwann cell proliferation and apoptotic death. Schwann cell and axon numbers are eventually matched such that within the first postnatal week in rodents, a one-to-one relationship between myelinating Schwann cells and large diameter axons has largely been attained, whereas nonmyelinating Schwann cells remain associated with multiple axons (Webster, 1993). The critical role of axons in the regulation of Schwann cell development during this period can primarily be ascribed to the provision of trophic factors (Reynolds and Woolf, 1993; Mirsky and Jessen, 1996; Zorick and Lemke, 1996). The postulated role of NRG-1 as an axon-derived Schwann cell mitogen (Fig. 2A) (Marchionni et al., 1993; Levi et al., 1995; Morrissey et al., 1995) and survival factor (Grinspan et al., 1996; Syroid et al., 1996; Trachtenberg and Thompson, 1996; Kopp et al., 1997) fits well within this mechanistic context, because NRG-1 is expressed in both developing and mature sensory and motoneurons (Carraway and Burden, 1995; Lemke, 1996). The results presented in this study identify IGF-I as an additional 

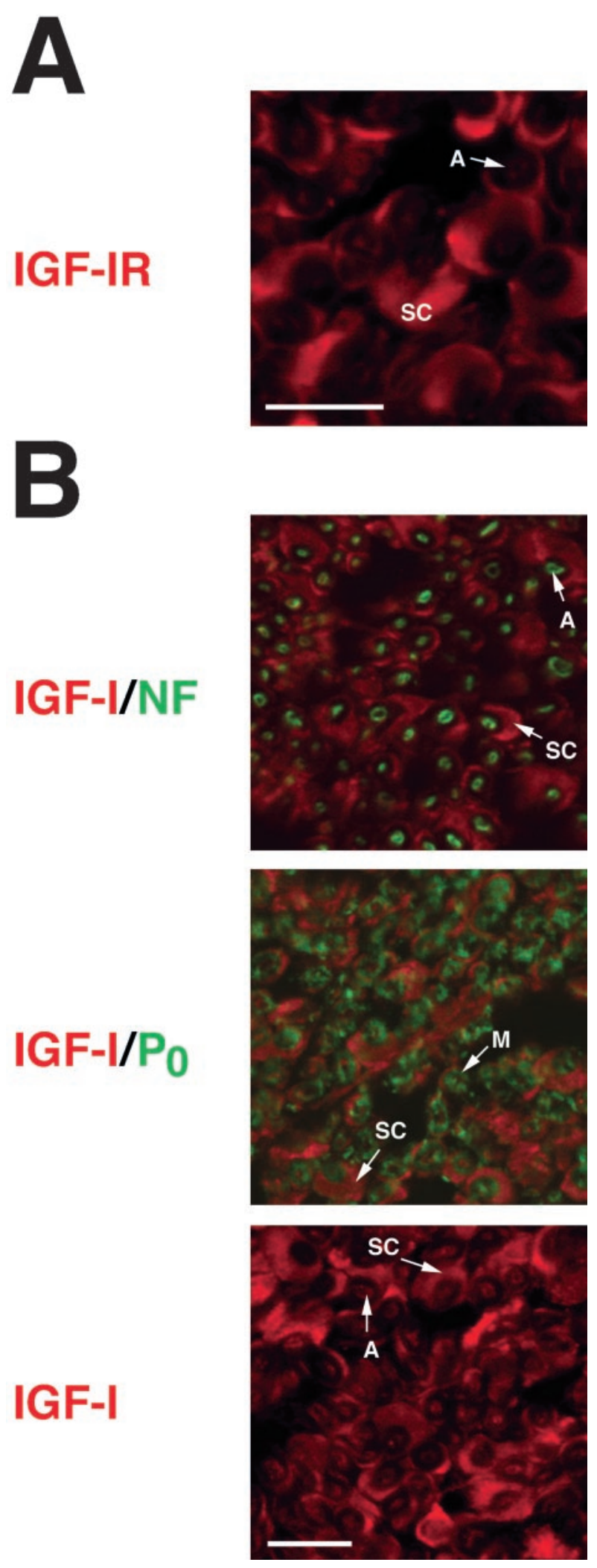

Figure 5. Schwann cells express $I G F-I R$ and $I G F-I$ throughout postnatal development. Immunohistochemical analyses were performed on cross sections of $\mathrm{P} 10$ rat sciatic nerve to examine IGF-I $R$ and $I G F-I$ protein expression. $A, I G F-I R$ protein (red) is localized primarily to Schwann cells $(S C)$, whereas axons $(A)$ also express a very low level of the $I G F-I R$. $B$, Double-labeling analyses were performed to examine $I G F-I$ protein expression (red) relative to axon-specific $N F$ protein expression (green) and myelin-specific $P_{0}$ protein expression (green), as indicated. IGF-I is

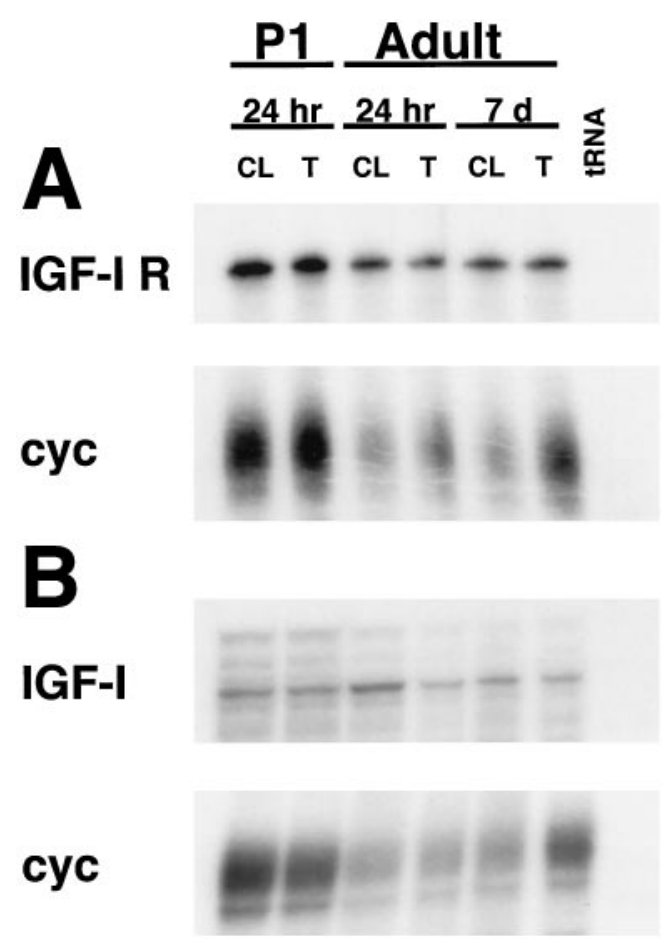

Figure 6. Expression of $I G F-I R$ and $I G F-I$ mRNA is maintained in the neonatal rat sciatic nerve during Wallerian degeneration. Unilateral transections of $P 1$ and adult rat sciatic nerve were performed, and ribonuclease protection analyses were performed using total RNA $(1 \mu \mathrm{g}$ per hybridization reaction) isolated from both the intact contralateral nerve $(C L)$ and the transected distal nerve stump (T) at $24 \mathrm{hr}$ and $7 \mathrm{~d}$ after transection or using $10 \mu \mathrm{g}$ of $t R N A$ as a negative control, as indicated. $A$, $B, I G F-I R(A)$ and $I G F-I(B)$ expression in the degenerating neonatal nerve is maintained at approximately the same level relative to that in the contralateral control nerve and is equivalent to that in degenerating adult nerves, at both $24 \mathrm{hr}$ and $7 \mathrm{~d}$ after transection. Bottom $(A, B)$, The relative cyclophilin gene expression $(c y c)$ from corresponding cohybridization reactions using the cyclophilin RNA probe is shown. We find that cyclophilin mRNA levels (which, like $\beta$-actin or glyceraldehyde phosphate dehydrogenase, are commonly used for loading controls in protection assays) are consistently lower in adult nerves relative to that in neonatal nerves (see Fig. 4), whereas cyclophilin mRNA levels increase in adult nerves undergoing Wallerian degeneration for an extended period $(7 \mathrm{~d})$. Autoradiographic exposure was $96 \mathrm{hr}(A)$ and $40 \mathrm{hr}(B)$.

trophic molecule that may regulate Schwann cell viability during postnatal development. However, because Schwann cells themselves are the major IGF-I ${ }^{+}$cell type in the neonatal nerve, our data suggest that axon-independent mechanisms also play an important role in controlling Schwann cell development. Because IGF-I, like NRG-1, is also capable of acting as a strong mitogen for cultured Schwann cells when assayed in combination with Fsk (Fig. 2A,B) (Schumacher et al., 1993; Stewart et al., 1996), it is likely that these molecules function together as important signals in the regulation of multiple stages (e.g., proliferation and survival) of Schwann cell development.

What are the molecular mechanisms that regulate Schwann cell viability during peripheral nerve development, and how does this

\section{$\leftarrow$}

highly expressed by Schwann cells $(S C)$. Although IGF-I immunoreactivity is excluded from the myelin sheath $(M)$, a very low level of $I G F-I$ protein also localizes to axons $(A)$. This is most evident in the bottom section immunostained for $I G F-I$ alone. Images were collected using a scanning confocal microscope. Scale bars, $10 \mu \mathrm{m}$. 
relate to the matching of Schwann cell and axonal numbers? The finding that transection of neonatal rat optic nerve gives rise to widespread oligodendrocyte cell death (Fulcrand and Privat, 1977; David et al., 1984; Barres et al., 1993) led Raff and colleagues to conclude that oligodendrocyte survival is critically dependent on axon-derived signals during postnatal development. These investigators have proposed a model in which the competition for limiting axon-derived trophic molecules serves to match correctly the number of oligodendrocytes to the number and length of axons they myelinate (Raff et al., 1993; Barres and Raff, 1994). Axonal interactions also control the survival of early postnatal Schwann cells. Transection of neonatal rat sciatic nerve results in an upregulation of Schwann cell apoptosis, and this axotomy-induced cell death can be prevented by the exogenous provision of NRG-1, indicating that NRG-1 is one such axonderived trophin for Schwann cells (Grinspan et al., 1996; Trachtenberg and Thompson, 1996; Kopp et al., 1997). Exogenous NRG-1 can also block naturally occurring Schwann cell death (Grinspan et al., 1996), indicating that the amount or availability of NRG-1 in the neonatal nerve may be limiting. These observations suggest that during early postnatal development, excess Schwann cells that either have lost axonal contact or are otherwise unable to secure limiting trophic support would become susceptible to apoptotic death and thus would be eliminated from the developing nerve.

However, the survival of only a fraction of postnatal Schwann cells is axon-dependent, because previous studies have shown that only a subset of Schwann cells are induced to undergo apoptotic death after transection of neonatal sciatic nerves (Grinspan et al., 1996; Trachtenberg and Thompson, 1996). These studies also demonstrate a progressive decrease in the proportion of Schwann cells subject to axotomy-induced apoptosis as transections are performed at progressively later stages of postnatal development. Indeed, little Schwann cell death can be detected after transection of mature sciatic nerves (Syroid, Kilpatrick, and Lemke, unpublished observations) (Weinberg and Spencer, 1978; Grinspan et al., 1996). These observations suggest that the survival requirements for Schwann cells switch to an axon-independent mechanism at later stages of postnatal development. Our results raise the interesting possibility that this later control of Schwann cell viability may, at least in part, require an IGF-I-mediated autocrine and/or paracrine loop. Such a loop would inhibit Schwann cell apoptosis after nerve injury and thereby promote axonal regeneration, which critically depends on the presence of Schwann cells (Fawcett and Keynes, 1990; Bunge, 1993; Son et al., 1996). In agreement with this hypothesis, mature peripheral nerves maintain regenerative capacity after injury (Fawcett and Keynes, 1990), while functional reinnervation by neonatal axons is impaired (McArdle and Sansone, 1977; Thompson and Jansen, 1977; Betz et al., 1980; Dennis and Harris, 1980), a difference that may be partially ascribed to the loss of Schwann cells through apoptotic death in neonates (Grinspan et al., 1996; Trachtenberg and Thompson, 1996; Kopp et al., 1997). Consistent with this model, Schwann cell expression of both IGF-I and the IGF-I R is maintained within injured and regenerating adult peripheral nerves (Fig. 6) (Hansson et al., 1986, 1987, 1988; Hansson, 1993; Glazner et al., 1994; Pu et al., 1995; Cheng et al., 1996).

Although our work strongly supports the hypothesis that IGF-I is a key component of Schwann cell survival regulation, the data presented above also indicate that IGF-I signaling by itself is unlikely to explain the observed switch to axon-independent survival that is seen in mature nerves, because we find that both the ligand and its receptor are expressed by Schwann cells from the day of birth. Why do some Schwann cells in the neonatal nerve undergo apoptosis during early postnatal development even though they express IGF-I (Figs. $4 B, 5 B$ )? Why do some developing Schwann cells remain susceptible to apoptotic death after loss of axonal contact, unlike mature Schwann cells in adult nerves undergoing Wallerian degeneration, even though both Schwann cell populations continue to express IGF-I R and IGF-I (Fig. 6)? There are several possibilities. (1) The subset of Schwann cells in the developing nerve that normally undergoes cell death and the enhanced proportion that die after transection may remain dependent on axonally derived trophic support and thus may represent a subset of Schwann cells that does not yet express IGF-I, (2) cell survival signaling pathways downstream of the IGF-I R may be impaired in the subset of immature Schwann cells that are susceptible to apoptosis, and (3) axon-derived or other Schwann cell-derived factors, in addition to IGF-I, may act in concert with IGF-I to support the survival of these early postnatal Schwann cells in vivo. With respect to this latter possibility, recent work has implicated NRG-1 itself in an autocrine and/or paracrine regulation of Schwann cell viability in developing and regenerating nerves (Raabe et al., 1996; Carroll et al., 1997; Rosenbaum et al., 1997).

In summary, the results reported above indicate that IGF-I, like NRG-1, is likely to play an important role in the control of Schwann cell viability during postnatal development and raise the interesting possibility that this regulation may switch in the early neonate from an axon-dependent mechanism to autocrine and/or paracrine signaling. In addition to the established roles for IGF-I in the development and maintenance of the CNS, our work provides further evidence that IGF-I is an important trophic molecule for peripheral nerve modeling and regeneration.

\section{REFERENCES}

Adamo ML, Ben-Hur H, Roberts Jr CT, LeRoith D (1991) Regulation of start site usage in the leader exons of the rat insulin-like growth factor-I gene by development, fasting, and diabetes. Mol Endocrinol 5:1677-1686.

Arbet-Engels C, Tartare-Deckert S, Eckhart W (1999) C-terminal Src kinase associates with ligand-stimulated insulin-like growth factor-I receptors. J Biol Chem, in press.

Barde YA (1989) Trophic factors and neuronal survival. Neuron 2:1525-1534.

Barres BA, Raff MC (1994) Control of oligodendrocyte number in the developing rat optic nerve. Neuron 12:935-942.

Barres BA, Jacobson MD, Schmid R, Sendtner M, Raff MC (1993) Does oligodendrocyte survival depend on axons? Curr Biol 3:489-497.

Beck KD, Powell-Braxton L, Widmer HR, Valverde J, Hefti F (1995) Igf1 gene disruption results in reduced brain size, CNS hypomyelination, and loss of hippocampal granule and striatal parvalbumincontaining neurons. Neuron 14:717-730.

Betz WJ, Caldwell JH, Ribchester RR (1980) The effects of partial denervation at birth on the development of muscle fibres and motor units in rat lumbrical muscle. J Physiol (Lond) 303:265-279.

Brockes JP, Fields KL, Raff MC (1979) Studies on cultured rat Schwann cells. I. Establishment of purified populations from cultures of peripheral nerve. Brain Res 165:105-118.

Bunge RP (1993) Expanding roles for the Schwann cell: ensheathment, myelination, trophism and regeneration. Curr Opin Neurobiol 3:805-809.

Caroni P, Grandes P (1990) Nerve sprouting in innervated adult skeletal muscle induced by exposure to elevated levels of insulin-like growth factors. J Cell Biol 110:1307-1317.

Carraway III KL, Burden SJ (1995) Neuregulins and their receptors. Curr Opin Neurobiol 5:606-612.

Carroll SL, Miller ML, Frohnert PW, Kim SS, Corbett JA (1997) Expression of neuregulins and their putative receptors, ErbB2 and ErbB3, is induced during Wallerian degeneration. J Neurosci 17:1642-1659. 
Carson MJ, Behringer RR, Brinster RL, McMorris FA (1993) Insulinlike growth factor I increases brain growth and central nervous system myelination in transgenic mice. Neuron 10:729-740.

Cheng HL, Randolph A, Yee D, Delafontaine P, Tennekoon G, Feldman EL (1996) Characterization of insulin-like growth factor-I and its receptor and binding proteins in transected nerves and cultured Schwann cells. J Neurochem 66:525-536.

Chomczynski P, Sacchi N (1987) Single-step method of RNA isolation by acid guanidinium thiocyanate-phenol-chloroform extraction. Anal Biochem 162:156-159.

Ciutat D, Caldero J, Oppenheim RW, Esquerda JE (1996) Schwann cell apoptosis during normal development and after axonal degeneration induced by neurotoxins in the chick embryo. J Neurosci 16:3979-3990.

Danielson PE, Forss-Petter S, Brow MAD, Calavetta L, Douglass J, Milner RJ, Sutcliffe JG (1988) p1B15: a cDNA clone of the rat mRNA encoding cyclophilin. DNA 7:261-267.

David S, Miller RH, Patel R, Raff MC (1984) Effects of neonatal transection on glial cell development in the rat optic nerve: evidence that the oligodendrocyte-type 2 astrocyte cell lineage depends on axons for its survival. J Neurocytol 13:961-974.

Dennis MJ, Harris AJ (1980) Transient inability of neonatal rat motoneurons to reinnervate muscle. Dev Biol 74:173-183.

de Pablo F, de la Rosa EJ (1995) The developing CNS: a scenario for the action of proinsulin, insulin and insulin-like growth factors. Trends Neurosci 18:143-150.

Dong Z, Brennan A, Liu N, Yarden Y, Lefkowitz G, Mirsky R, Jessen KR (1995) Neu differentiation factor is a neuron-glia signal and regulates survival, proliferation, and maturation of rat Schwann cell precursors. Neuron 15:585-596.

Fawcett JW, Keynes RJ (1990) Peripheral nerve regeneration. Annu Rev Neurosci 13:43-60.

Fraser A, McCarthy N, Evan GI (1996) Biochemistry of cell death. Curr Opin Neurobiol 6:71-80.

Fulcrand J, Privat A (1977) Neuroglial reactions secondary to Wallerian degeneration in the optic nerve of the postnatal rat: ultrastructural and quantitative study. J Comp Neurol 176:189-224.

Garcia-Segura LM, Perez J, Pons S, Rejas MT, Torres-Aleman I (1991) Localization of insulin-like growth factor I (IGF-I)-like immunoreactivity in the developing and adult rat brain. Brain Res 560:167-174.

Gavrilovic J, Brennan A, Mirsky R, Jessen KR (1995) Fibroblast growth factors and insulin growth factors combine to promote survival of rat Schwann cell precursors without induction of DNA synthesis. Eur J Neurosci 7:77-85.

Glazner GW, Morrison AE, Ishii DN (1994) Elevated insulin-like growth factor (IGF) gene expression in sciatic nerves during IGFsupported nerve regeneration. Mol Brain Res 25:265-272.

Grinspan JB, Marchionni MA, Reeves M, Coulaloglou M, Scherer SS (1996) Axonal interactions regulate Schwann cell apoptosis in developing peripheral nerve: neuregulin receptors and the role of neuregulins. J Neurosci 16:6107-6118.

Hansson H-A (1993) Insulin-like growth factors and nerve regeneration. Ann NY Acad Sci 692:161-171.

Hansson H-A, Dahlin LB, Danielsen N, Fryklund L, Nachemson AK, Polleryd P, Rozell B, Skottner A, Stemme S, Lundborg G (1986) Evidence indicating trophic importance of IGF-I in regenerating peripheral nerves. Acta Physiol Scand 126:609-614.

Hansson H-A, Rozell B, Skottner A (1987) Rapid axoplasmic transport of insulin-like growth factor I in the sciatic nerve of adult rats. Cell Tissue Res 247:241-247.

Hansson H-A, Dahlin LB, Lowenadler B, Lundborg G, Paleus S, Skottner A (1988) Transient increase in insulin-like growth factor I immunoreactivity in rat peripheral nerves exposed to vibrations. Acta Physiol Scand 132:35-41.

Hasel KW, Sutcliffe JG (1990) Nucleotide sequence of a cDNA coding for mouse cyclophilin. Nucleic Acids Res 18:4019.

Ishii DS, Glazner GW, Whalen LR (1993) Regulation of peripheral nerve regeneration by insulin-like growth factors. Ann NY Acad Sci 692:172-182.

Jones JI, Clemmons DR (1995) Insulin-like growth factors and their binding proteins: biological actions. Endocr Rev 16:3-34.

Kopp DM, Trachtenberg JT, Thompson WJ (1997) Glial growth factor rescues Schwann cells of mechanoreceptors from denervation-induced apoptosis. J Neurosci 17:6697-6706.

Krieg PA, Melton DA (1987) In vitro RNA synthesis with SP6 RNA polymerase. Methods Enzymol 155:397-415.
Lemke G (1996) Neuregulins in development. Mol Cell Neurosci 7:247-262.

Lemke G, Chao M (1988) Axons regulate Schwann cell expression of the major myelin and NGF receptor genes. Development 102:499-504.

LeRoith D, Werner H, Beitner-Johnson D, Roberts Jr CT (1995) Molecular and cellular aspects of the insulin-like growth factor I receptor. Endocr Rev 16:143-163.

Levi ADO, Bunge RP, Lofgren JA, Meima L, Hefti F, Nikolics K, Sliwkowski MX (1995) The influence of heregulins on human Schwann cell proliferation. J Neurosci 15:1329-1340.

Lewis ME, Neff NT, Contreras PC, Stong DB, Oppenheim RW, Grebow PE, Vaught JL (1993a) Insulin-like growth factor-I: potential for treatment of motor neuronal disorders. Exp Neurol 124:73-88.

Lewis ME, Vaught JL, Neff NT, Grebow PE, Callison KV, Yu E, Contreras PC, Baldino Jr F (1993b) The potential of insulin-like growth factor-I as a therapeutic for the treatment of neuromuscular disorders. Ann NY Acad Sci 692:201-208.

Lievre CA-L, Stahlbom P-A, Sara VR (1991) Expression of IGF-I and -II mRNA in the brain and craniofacial region of the rat fetus. Development 111:105-115.

Liu JP, Baker J, Perkins AS, Robertson EJ, Efstratiadis A (1993) Mice carrying null mutations of the genes encoding insulin-like growth factor I (Igf-1) and type 1 IGF receptor (Igf1r). Cell 75:59-72.

Marchionni MA, Goodearl AD, Chen MS, Bermingham-McDonogh O, Kirk C, Hendricks M, Danehy F, Misumi D, Sudhalter J, Kobayashi K, Wroblewski D, Lynch C, Baldassare M, Hiles I, Davis JB, Hsuan JJ, Totty NF, Otsu M, McBurney RN, Waterfield MD, Stroobant P, Gwynne D (1993) Glial growth factors are alternatively spliced erbB2 ligands expressed in the nervous system. Nature 362:312-318.

McArdle JJ, Sansone FM (1977) Re-innervation of fast and slow twitch muscle following nerve crush at birth. J Physiol (Lond) 271:567-586.

McMorris FA, Dubois-Dalcq M (1988) Insulin-like growth factor I promotes cell proliferation and oligodendroglial commitment in rat glial progenitor cells developing in vitro. J Neurosci Res 21:199-209.

McMorris FA, Smith TM, DeSalvo S, Furlanetto RW (1986) Insulin-like growth factor I/somatomedin C: a potent inducer of oligodendrocyte development. Proc Natl Acad Sci USA 83:822-826.

McMorris FA, Mozell RL, Carson MJ, Shinar Y, Meyer RD, Marchetti N (1993) Regulation of oligodendrocyte development and central nervous system myelination by insulin-like growth factors. Ann NY Acad Sci 692:321-334.

Mirsky R, Jessen KR (1996) Schwann cell development, differentiation and myelination. Curr Opin Neurobiol 6:89-96.

Morrissey TK, Levi ADO, Nuijens A, Sliwkowski MX, Bunge RP (1995) Axon-induced mitogenesis of human Schwann cells involves heregulin and p185erbB2. Proc Natl Acad Sci USA 92:1431-1435.

Mozell RL, McMorris FA (1991) Insulin-like growth factor I stimulates oligodendrocyte development and myelination in rat brain aggregate cultures. J Neurosci Res 30:382-390.

Nakao J, Shinoda J, Nakai Y, Murase S, Uyemura K (1997) Apoptosis regulates the number of Schwann cells at the premyelinating stage. J Neurochem 68:1853-1862.

Oppenheim RW (1991) Cell death during development of the nervous system. Annu Rev Neurosci 14:453-501.

Pu S-F, Zhuang H-X, Ishii DN (1995) Differential spatio-temporal expression of the insulin-like growth factor genes in regenerating sciatic nerve. Mol Brain Res 34:18-28.

Raabe TD, Clive DR, Neuberger TJ, Wen D, DeVries GH (1996) Cultured neonatal Schwann cells contain and secrete neuregulins. J Neurosci Res 46:263-270.

Raff MC (1992) Social controls on cell survival and cell death. Nature 356:397-400.

Raff MC, Barres BA, Burne JF, Coles HS, Ishizaki Y, Jacobson MD (1993) Programmed cell death and the control of cell survival: lessons from the nervous system. Science 262:695-700.

Reinhardt RR, Chin E, Zhang B, Roth RA, Bondy CA (1993) Insulin receptor-related receptor messenger ribonucleic acid is focally expressed in sympathetic and sensory neurons and renal distal tubule cells. Endocrinology 133:3-10.

Reynolds ML, Woolf CJ (1993) Reciprocal Schwann cell-axon interactions. Curr Opin Neurobiol 3:683-693.

Rosenbaum C, Karyala S, Marchionni MA, Kim HA, Krasnoselsky AL, Happel B, Isaacs I, Brackenbury R, Ratner N (1997) Schwann cells express NDF and SMDF/n-ARIA mRNAs, secrete neuregulin, and 
show constitutive activation of erbB3 receptors: evidence for a neuregulin autocrine loop. Exp Neurol 148:604-615.

Saneto RP, Low KG, Melner MH, de Vellis J (1988) Insulin/insulin-like growth factor I and other epigenetic modulators of myelin basic protein expression in isolated oligodendrocyte progenitor cells. J Neurosci Res 21:210-219.

Schumacher M, Jung-Testas I, Robel P, Baulieu EE (1993) Insulin-like growth factor I: a mitogen for rat Schwann cells in the presence of elevated levels of cyclic AMP. Glia 8:232-240.

Son YJ, Trachtenberg JT, Thompson WJ (1996) Schwann cells induce and guide sprouting and reinnervation of neuromuscular junctions. Trends Neurosci 19:280-285.

Steller H (1995) Mechanisms and genes of cellular suicide. Science 267:1445-1449.

Stewart HJ, Bradke F, Tabernero A, Morrell D, Jessen KR, Mirsky R (1996) Regulation of rat Schwann cell Po expression and DNA synthesis by insulin-like growth factors in vitro. Eur J Neurosci 8:553-564.

Syroid DE, Maycox PR, Burrola PG, Liu N, Wen D, Lee KF, Lemke G, Kilpatrick TJ (1996) Cell death in the Schwann cell lineage and its regulation by neuregulin. Proc Natl Acad Sci USA 93:9229-9234.

Thompson W, Jansen JKS (1977) The extent of sprouting of remaining motor units in partly denervated immature and adult rat soleus muscle. Neuroscience 2:523-535.

Trachtenberg JT, Thompson WJ (1996) Schwann cell apoptosis at de- veloping neuromuscular junctions is regulated by glial growth factor. Nature 379:174-177.

Webster HdeF (1993) Development of peripheral nerve fibers. In: Peripheral neuropathy, 3rd Edition (Dyck PJ, Thomas PK, Griffin JW, Low PA, Poduslo JF, eds), pp 243-266. Philadelphia: Saunders.

Weinberg HJ, Spencer PS (1978) The fate of Schwann cells isolated from axonal contact. J Neurocytol 7:555-569.

Werner H, Woloschak M, Adamo M, Shen-Orr Z, Roberts Jr CT, LeRoith D (1989) Developmental regulation of the rat insulin-like growth factor I receptor gene. Proc Natl Acad Sci USA 86:7451-7455.

White E (1996) Life, death, and the pursuit of apoptosis. Genes Dev 10:1-15.

Yao DL, Liu X, Hudson LD, Webster HdeF (1995) Insulin-like growth factor I treatment reduces demyelination and up-regulates gene expression of myelin-related proteins in experimental autoimmune encephalomyelitis. Proc Natl Acad Sci USA 92:6190-6194.

Ye P, Carson J, D'Ercole AJ (1995) In vivo actions of insulin-like growth factor-I (IGF-I) on brain myelination: studies of IGF-I and IGF binding protein-1 (IGFBP-1) transgenic mice. J Neurosci 15:7344-7356.

Zorick TS, Lemke G (1996) Schwann cell differentiation. Curr Opin Cell Biol 8:870-876.

Zorick TS, Syroid DE, Arroyo E, Scherer SS, Lemke G (1996) The transcription factors SCIP and Krox-20 mark distinct stages and cell fates in Schwann cell differentiation. Mol Cell Neurosci 8:129-145. 